\title{
Predicting Intention of Using Fintech Lending to Bank Users in Indonesia
}

\author{
Bayudha Desga Putranto ${ }^{1 *} \&$ Nurdin Sobari ${ }^{2}$
}

\author{
${ }^{1}$ Universitas Indonesia, Depok, Indonesia \\ ${ }^{2}$ Universitas Indonesia, Depok, Indonesia \\ *Corresponding author.Email: bayuyuda72@gmail.com
}

\begin{abstract}
The significant increase in the use of fintech lending proves the vital role of non-banks in providing innovative online payment services and cash funds facilities. However, not many have specifically examined the focus on one type of fintech, namely fintech lending. This study's purpose is to examines the structural relationship between perceived ease of use, perceived usefulness, brand image, government support, user innovativeness, perceived risk, trust, subjective norm, perceived behavioral control, attitude, and intention to use lending fintech in Indonesia. This research is based on the Theory of Reason Action (TRA), Theory Acceptance Model (TAM), and Theory of Planned Behavior (TPB). A total of 377 nonfintech lending users and bank users were collected to test research using Structural Equation Modeling. The results provide eight proposed hypotheses that management can use and provide alternatives for financial services companies.
\end{abstract}

Keywords: Fintech lending, consumer behavior, TRA, TAM, TPB.

\section{INTRODUCTION}

The current digitalization flow in the economy and finance is changing the behavior of economic agents. Today's people want financial services that are fast, economical, and safe. There have been so many stimuli from various types of fintech applications that have sprung up with the hope of getting a positive attitude from consumers, resulting in an intention to adopt fintech in everyday life. The Financial Services Authority (OJK) in 2020 shows a significant increase, which explains that the total number of online loans disbursed to the Indonesian people by the end of 2020 was 155.9 trillion with 43.5 million borrower accounts. This data shows that there is a positive growth of $91 \%$ when compared to the 2019 position.

The Indonesia has the most prospective consumer segment to absorb the wave of digitalization which is translated as the attitude in using fintech lending. This generation is the population that gets exposure to the public interest in digital literacy stimulated by the role of digital natives in that generation. The focus of this study is to determine the factors that influence a person to become a first adopter of fintech lending services. The banking industry in Indonesia has challenges. The presence of fintech is seen as a disruption to conventional financial institutions, services, and products.

Fintech lending - also known as Peer-toPeer Lending is defined as an innovation in the financial sector by utilizing technology that allows lenders and loan recipients borrower) to carry out lending and borrowing transactions without having to meet in person. As of February 2020, there were 161 fintech lending companies, consisted of 25 with business licenses and 136 registered with the Financial Services Authority. version of your paper onto this new formatted file. 


\subsection{Attitudes and intentions theory of research model}

In the early 1960s, the prevailing assumption was that attitudes and behaviors were closely related to attitude-determined behavior, as evidenced by research that repeatedly showed a strong relationship between attitude and behavior (Fishbein \& Ajzen 1977) in TRA. They propose TPB as the intention to do rather than the attitude towards behavior that determines behavior. The TPB theory explains the illustration of intentions being influenced by attitudes, subjective norms, and PBC. The TAM model divides the factors that influence individual behavioral attitudes, namely perceived usefulness and PEU, which significantly impact adopting new technology (Davis 1986). Some of the variables in this study were built by several recent researchers in the period (20182020), explaining that BI, GS, and UI (Hu et al. 2019 and Zhang et al. 2018) have a positive influence on the adoption of fintech services. Second, PR affects ATT users through TRU (Hu et al. 2019 and Zhang et al. 2018). PEU does not significantly affect fintech adoption (Hu et al. 2019 and Luna et al. 2018).

In PR and PEU, the results show no significant effect on ATT in using fintech. There are limitations to $\mathrm{Hu}$ et al. 2019); the research has not considered psychological factors such as social influence and selfefficacy. Darmansyah et al. (2020) investigate the factors that influence behavioral intention to use Islamic fintech payments, P2P lending, and crowdfunding with the study results show TPB, TAM, use of technology are variables that have a significant impact on encouraging behavioral intention.

\subsection{Brand Image}

Consistent with the associative network memory model of brand knowledge, brand image is conceptualized as a perception of a brand as expressed by brand associations stored in the minds of consumers (Keller
1993). Brand image is an intangible asset with economic value, which shows its difference from an abstract and distinctive concept that can be identified. Brand image results in a comprehensive positive effect reflection on users (Hu et al. 2019). Therefore, we hypothesize the following:

$\mathrm{H} 1$ : Brand image has a positive influence on attitude.

\subsection{Government support}

Government support is one of the biggest drivers in fintech adoption because carrying the name government will increase credibility (Hu et al., 2019). Government support is critical in creating online trust in financial products (Marakarkandy et al. 2017). Through regulations that are made, the government can encourage or prevent technological innovations (Lin \& Ho 2009 instead of $\mathrm{Hu}$ et al. 2019). Based on this description, the researchers formulate the following hypothesis:

H2: Government support has a positive effect on attitude.

\subsection{User innovativeness}

Government User innovation is the level of an individual willing to experiment with new products (Lu et al. 2005 instead of $\mathrm{Yu}$ et al. 2018). Hu et al. (2019) say that user innovation is defined as the initial adoption rate of a particular innovation by an individual. User innovation is the level of an individual's propensity to try a new product, new technology, or service. Zhang et al. (2018) also proves that consumer innovation could provide a positive attitude because it is an emotional reaction to the pleasure of being the first to adopt a technology. Based on this description, the researchers formulate the following hypothesis:

H3: User innovativeness has a positive effect on attitude. 


\subsection{Trust}

Trust is the belief in integrity, virtue, competence, and abilities of others (Zhang et al. 2018). Trust has always been the focus of research on adoption issues, often used as an essential basis for measuring technology user interest (Hu et al. 2019). In all lines, mobile technology allows virtual customers to buy and consume services in an online environment, increasing transaction risk (Zhang et al. 2018). In the fintech application scenario, trust is more important because the term high data usage is very involved in fintech services (Hu et al. 2019). Based on this description, the researcher formulated the following hypothesis:

H5: Trust in the apps has a positive effect on attitude.

\subsection{Perceived usefulness}

Trust Davis (1986) says that perceived usefulness is the level of belief that using a particular system can improve job performance. In the Technology Acceptance Model (TAM), the benefits received play a role in how much a customer feels that renewable technology can be useful. Luna et al. (2018) instead of Hu et al. (2019) and Zhang et al. (2018) prove that perceived usefulness affects attitude in cases of financial technology adoption. Therefore, the following hypothesis is proposed:

H10: Perceived usefulness has a positive effect on attitude.

\subsection{Perceived ease of use}

Davis (1986) defines perceived ease of use as a person's belief that using a particular system will facilitate the effort. The perceived convenience of being able to convince users of the technology used is something that is easy and is not a burden for them. Likewise, the opinion of Luna et al. (2018) instead of $\mathrm{Hu}$ et al. (2019) reveals that perceived ease of use affects perceived usefulness. However, only $\mathrm{Hu}$ et al. (2019) stipulate that perceived usefulness affects attitude in technology adoption. Based on this description, the researchers formulate the following hypotheses:

H8: Perceived ease of use has a positive effect on perceived usefulness.

H9: Perceived ease of use has a positive effect on attitude.

\subsection{Perceived risk}

Ryu (2018) explains that risk is salient beliefs that determine consumer decisions in using fintech. Perceived risk is a form of lack of trust and a significant factor negatively influencing technology adoption by Ryu (2018). Financial risk refers to damage caused by consumer concerns about product results and negligence. Privacy risk refers to the risk of personal data, transaction data, and other private information that consumers disclose when choosing digital financial products (Hu et al. 2019). Based on this description, the researchers formulate the following hypothesis:

H4: Perceived risk has a negative effect on attitude.

\subsection{Attitude}

Attitudes are multidimensional constructs consisting of cognitive, affective, and conative factors that form behavior (Fishbein \& Ajzen 1977). The cognitive component refers to what a person knows about a product or service (experiences, beliefs, and opinions). The affective component refers to an individual's tastes about an object (feelings, emotions, and values). The cognition component refers to behavioral intentions. (purchase value, purchase response, and rejection response) (Alonso \& Grande 2004 instead of Ryu 2018). In the theory of plan behavior (TPB) by Ajzen (1991), attitudes toward behavior are people's tendency to respond to like or dislike things in an object, person, institution, or event. Based on this description, the researchers formulate the following hypothesis: 
H12: Attitude has a positive effect on intention to use.

\subsection{Subjective Norm}

According to Ajzen (1991), the term subjective norm, namely benefits that have a basis for belief, is often referred to as a normative belief. Normative belief is belief in an understanding or group that affects an individual's behavior. The crucial social influence of several behaviors is rooted in family, spouse, co-workers, relatives, and other behavioral references (Ajzen 1991). Social power is an essential part of the subjective norm, which is implemented through rewards and punishments conveyed by individuals to other individuals (Fishbein \& Ajzen 1977). Social influence in the form of subjective norms is used as a factor in technology acceptance models and later stages of adaptation (Vankatesh \& Bala 2008). Based on this description, the researchers formulate the following hypotheses:

H6: Subjective norm has a positive effect on perceived ease of use.

H7: Subjective norm has a positive effect on perceived usefulness.

H11: Subjective norm has a positive influence on intention to use.

\subsection{Perceived behavioral control}

The construct of perceived behavioral control is similar to the concept of self-efficacy theory, which is related to a person's perception of the ability to perform a behavior. In contrast, behavioral control is related to perceived control over the performance of behavior or how easy/difficult it is to do the behavior (Ajzen 1991). A set of belief controls influences behavioral control. It is a person's belief that affects/inhibits behavioral performance; construct influences how easy or difficult it is to do the behavior (Ajzen 1991).

H13: Perceived behavioral control has a positive effect on intention to use.

\section{RESEARCH METHODS}

The researcher used a purposive sampling technique with the criteria of banking customer respondents aged 21-34 years, have a fund account for six months and/or had become consumer credit debtor customers. Customers were non-users / have never applied for a fintech lending to apply for a loan through fintech. A total of 377 respondents were deemed sufficient because they had exceeded the minimum sample requirements suggested by Bentler \& Chou (1987) with a ratio of 5: 1, which required five times the number of parameters. In this research, there are 51 questions, so the minimum sample that must be obtained is 265 respondents.

To ensure the validity of the research content, we modified the indicators from previous research to suit the fintech context. Indicators used for PEU (5 items) and PU (5 items), BI (5 items), GS (5 items), UI (3 items), PR (6 items), TRU (6 items), SN (4 items), PBC (3 items), ATT (5 items), and INT (5 items). A five-point Likert scale ranging from $1-5$ is used to measure all items. A pre-test on 30 fintech users was carried out to validate the instrument.

\section{RESULTS AND DISCUSSIONS}

The demographic profile is described as follows: most of the respondents were females $(65 \%)$ than males $(35 \%)$. The age of the respondents was between 21-24 years (30\%), 25-29 years (54\%), and 30-34 years $(15.6 \%)$. Most respondents were working as State-own enterprises (36.3\%), privateemployees $(35 \%)$, and others are civil servants $(11.7 \%)$, students $(10.3 \%)$, unemployed $(2,9 \%)$, entrepreneurs, and professionals (3.7\%). In terms of educational qualifications, most of them were Bachelor/Diploma$4 \quad(79.6 \%)$, followed by Master/Doctorate/Profession (8.2\%), High school/equivalent (8.2\%), and Diploma-3 $(4.5 \%)$. In terms of income, most respondents have monthly income of 3-6 million (37.7\%), 6-9 million (23.3\%), 9-12 million 
$(14.9 \%),<3$ million $(14,1 \%)$, and $>12$ million $(10.1 \%)$. Based on monthly consumptive expenditure, which is dominated by monthly expenditures of $1.8-4.5$ million (52.8\%), 0.9-1.8 million (22.3\%), 4.5-6 million $(17.2 \%),<0.9$ million $(5.3 \%),>9$ million $(2.1 \%)$, and 6-9 million $(0.3 \%)$.

This research model was analyzed using Structural Equation Model (SEM) - Partial Least Square (PLS) with Smart PLS 3.3.3 software. The PLS technique is a predictionoriented technique optimal for prediction accuracy and model accuracy. This technique is suitable in research times because the structural model is quite complex (many constructs and many indicators). PLS-SEM was applied as an alternative to CB-SEM, given its ability to analyze small sample sizes and abnormally distributed data (Rigdon et al., 2017).

This research model was analyzed using Structural Equation Model (SEM) - Partial Least Square (PLS) with Smart PLS 3.3.3 software. The PLS technique is a predictionoriented technique optimal for prediction accuracy and model accuracy. This technique is suitable in research times because the structural model is quite complex (many constructs and many indicators). PLS-SEM was applied as an alternative to CB-SEM, given its ability to analyze small sample sizes and abnormally distributed data.

Loading factors for most items were above the recommended value of 0.7 . There is an outer loading value that is lower than 0.7 , namely PBC 1 (0.532), PBC 3 (0.632), and PU1 (0.687). This value is acceptable, according to Hair et al. (2014). In addition, the AVE value obtained is in the range of $0.532-0.843$; the construct can be said to be valid if the AVE value is $>0.5$. Furthermore, the composite reliability value is used to show the internal consistency of a latent variable indicator. The $\mathrm{CR}$ of each construct produces a value more than the tolerance limit of 0.7 , so it is concluded that 11 constructs are reliable. All construct variables with their indicators are higher than the correlation indicators for other variables. This shows that each construct on the built varia- ble can predict the indicators in each construct better than the indicators in other constructs. Discriminant validity compares the AVE / Average Variance Extracted roots for each construct with the correlation between constructs in the model. This value can be seen from the results of the Fornell-Lacker Criterion, which has good discriminant validity if the AVE root for each construct is higher than the correlation value. Overall, the measurement model confirms that convergent validity and discriminant validity are sufficiently well developed.

To get the structural model test values (Inner model), a model that connects between constructs can be measured and evaluated using bootstrapping calculations, followed by path coefficient analysis, RSquare, and total effects. Eight of the thirteen hypotheses $(\mathrm{H} 3, \mathrm{H} 5, \mathrm{H} 6, \mathrm{H} 7, \mathrm{H} 8, \mathrm{H} 11$, $\mathrm{H} 12$, and H13) are supported and significant in the SEM-PLS prediction, except for $\mathrm{H} 1$, $\mathrm{H} 2, \mathrm{H} 4, \mathrm{H} 5, \mathrm{H} 9$, and H10. The R-square value of the Attitude (ATT) variable is 0.505 , and the Intention (INT) is 0.666 , indicating that the model is "moderate" because the value is in the range of 0.33-0.67. Meanwhile, the R-square value of the PEU variable is $0.107 \mathrm{PU}$ of 0.328 , indicating that the model is "weak".

The results of the indirect effect measurement prove that in the model, there are two important chains of significant mediation relationships, namely, (UI) to INT, through ATT attitude) $(\beta=0.174, \mathrm{p}<0.01)$, and TRU to INT, through ATT $(\beta=0.241, p$ $<0.01)$. It is concluded that ATT is significant in mediating the influence of UI and TRU on INT. The model measurement stage is continued by measuring the predictive relevance (Q2), which is useful for evaluating the accuracy of the proposed model. The value of Q2 can be seen in the PU variable (0.199), PEU (0.070). Meanwhile, Attitude $(0.375)$ and INT $(0.516)$ have a greater predictive value. Value of Q2>0 shows evidence that the observed values have been constructed properly so that the model has predictive relevance. In this study, the SRMR value is 0.06 , so that this model is fit, 
values $<0.1$ or $<0.08$ are considered suitable. The NFI score is also one of the first fit measures proposed in the SEM literature (Bentler \& Bonett 1980 instead of Belanche et al. 2019). The closer the NFI value is to 1 , the better the match will be. In this study, the NFI value is 0.813 , and this value indicates a good model.

\section{CONCLUSION}

Our model has integrated 11 variables with the dimensions of the TPB model, which is the development of TRA, and TAM, which are the PEU construct, PEU, ATT, SN, PBC, and INT, and adopted fintech-related research constructs, namely BI, UI, GS, PR, and TRU. We find support for thirteen hypotheses with a sample of banking customers who have not used fintech lending.

Several indicator questions are more suitable to be asked of respondents who have used fintech lending. The use of wrong words can confuse respondents or create bias in filling out the questionnaire. The following research is interesting to examine the intention to use fintech lending from the lender's perspective (lender).

\section{REFERENCES}

Ajzen, I. 1991. The theory of planned behavior. Organizational Behavior and Human Decision Processes 50(2).

Belanche, D. Casaló, L.V. \& Flavián, C. 2019. Artificial Intelligence in FinTech: understanding roboadvisors adoption among customers. Industrial Management \& Data Systems.

Bentler, P.M. \& Chou, C.P. 1987. Practical issues in structural modeling. Sociological methods \& research 16(1): 78-117.

Darmansyah. Fianto, BA. Hendratmi, A. 2020. Factors determining behavioral intentions to use Islamic financial technology. Journal of Islamic Marketing. 1759-0833 DOI 10.1108/JIMA-122019-0252.

Luna, I.R. Cabanillas, F.L. Fernandez, J.S. Leiva, F. 2018. Mobile payment is not all the same: The adoption of mobile payment systems depending on the technology applied. Technological Forecasting \& Social Change. https://doi.org/10.1016/j.techfore.2018.09.018
Davis, F.D. 1986. A technology acceptance model for empirically testing new end-user information systems. Dissertation. Cambridge: Massachusetts Institute of Technology.

Fishbein, M. \& Ajzen, I. 1977. Belief, attitude, intention, and behavior: An introduction to theory and research. Contemporary Sociology 6(2): 244-245.

Hu, Z. Ding, S. Li, S. Chen, L. \& Yang, S. 2019. Adoption intention of fintech services for bank users: An empirical examination with an extended technology acceptance model. Symmetry 11(3): 340.

Keller, K.L. 1993. Conceptualizing, measuring, and managing customer-based brand equity. The Journal of Marketing 1(22).

Kim, C.; Mirusmonov, M.; Lee, I. An Empirical Examination of Factors Influencing the Intention to Use Mobile Payment. Comput. Hum. Behav. 2010, 26, 310-322.

Marakarkandy, B. Yajnik, N. Dasgupta, C. 2017. Enabling Internet Banking Adoption: An Empirical Examination with an Augmented Technology Acceptance Model (Tam). Journal Entrepreneurship Information Management 30: 263-294.

Ryu, H.S. 2018. What makes users willing or hesitant to use fintech? The moderating effect of user type. Industrial Management and Data Systems 118(3): 541-569.

Venkatesh, V. \& Bala, H. 2008. Technology acceptance model 3 and a research agenda on interventions. Decision sciences 39(2): 273-315.

Yu, M. Liu, F. Lee, J. \& Soutar, G. 2018. The influence of negative publicity on brand equity: attribution, image, attitude and purchase intention. Journal of Product \& Brand Management.

Zhang, T. Lu, C. \& Kishida, M. 2018. Banking 'onthe-go': examining consumers' adoption of mobile banking services. International Journal of Quality and Service Sciences 10(3): 279-295. 